Volume-IX, Issue-01, January-June, 2014

\title{
Exploitation of Social Networking Sites and Its Impacts on Students' Academic Results: A Quest for Correlation or Misspecification in Bangladesh
}

\author{
THAWHIDUL KABIR* \\ SHIRIN AKTER ${ }^{* *}$ \\ ZANNATUL FERDUS ${ }^{* * *}$
}

\begin{abstract}
Social networking sites have become the inevitable part of everyone's life. Large numbers of students in Bangladesh spend a lion share of daily time by wandering through online social networking sites. So it is imperative to mention the effects of using social networking sites on the society. This study aims to analyse whether the use of social networking sites can influence students' academic results or not. To get the desired answer, a random sample, constituted with 1182 university students from Dhaka Metropolitan City, Bangladesh, was drawn and surveyed with self-administered questionnaire. This study significantly found that, students achieved average results in last two semesters were inversely influenced by their hours of regular involvement in different social networking sites (SNSS), and also by the use of different mobile messaging applications (MMAs). Based on the finding, this study concludes that, students' involvement in different SNSs and MMAs in terms of hours should be closely monitored to mitigate the aforesaid inverse effects.
\end{abstract}

Keywords: Social Networking Sites, Mobile Messaging Applications, Academic Result, Frequency of Using Network.

* Assistant Professor, Department of Management, Bangladesh University of Business \& Technology. Email: tawhidulkabir@yahoo.com

** Lecturer, Department of Management, Bangladesh University of Business \& Technology. Email: shirinsumi2013@gmail.com

*** Lecturer, Department of Management, Bangladesh University of Business \& Technology. Email: ferduszannatul@gmail.com 


\section{INTRODUCTION}

Internet was introduced in Bangladesh through an UUCP (Unix-to-Unix copy) email connectivity in 1993 by Pradesta Ltd. (Rahman, 2002), and the online Internet service activated in June 1996 when VSAT (Very Small Aperture Terminal), a satellite communications system, was legalized by Bangladesh Telegraph and Telephone Board

(BTTB).The Board gave VSAT permission to two Internet service providersInformation Services Network (ISN) and Grameen Cybernet, to install VSAT data circuits in the same year (Azam, 2007; Internet World Stats, 2004; and Rahman, 2002). At that moment, the Internet penetration rate in Bangladesh was as low as $0.2 \%$, compared to Thailand $9.3 \%$, Maldives $5.2 \%$, Vietnam $4.2 \%$, India 1.7\%, Pakistan 1.0\%, and Sri Lanka 1.0\% (Internet World Stats, 2004). Later, Bangladesh has officially been connected with the world's information super highway, submarine optic fibre cable network on 21st May, 2006, which has facilitated Bangladesh to get more faster access in Internet, and hence, Bangladesh's ICT position has been ranked at 6th among the seven SAARC countries (Azam, 2007). Now, Bangladesh is treated as a growing ICT (Information and Communication Technology) country in the world where the rate of internet use is increasing day by day (Mahmud,2011) and, as consequences, there has been much talk about the use of Internet in industry, business, communication, education, research, and in every other sphere of life (Internet World Stats, 2004).

\section{LITERATURE REVIEW}

Previous researchers have significantly addressed and documented different aspects of internet use in Bangladesh. Rahman, (2002) has evaluated the internet and its access; Lane (2006) has conducted a case study for the GSM association; Roknuzzaman (2006) has conducted a survey on internet access in a large public university; Alam, Kabir, and Elizabeth (2006) have looked at the implementation and evaluation of e-learning; Islam and Selim (2006) have examined the current status and prospects for e-learning in the promotion of distance education; Azam (2007) has studied the internet adoption and its usage; Debnath and Mahmud (2007) have scrutinized the E-commerce environment; Mohseni, Dowra and Haghighat(2008) have investigated whether the use of internet is making people socially isolated or not; Islam and Grönlund (2011) have studied the pros and 
cons of the digitalization process in Bangladesh, Islam and Ahamed (2011) have evaluated customers' attitude towards wireless internet; Mostofa (2011) has scanned the access and use of internet among business students of a private university of Bangladesh; Mahmud (2011) has checked up the private university student's attitudes towards internet; Akhter, Siddique and Masum (2011) have analyzed the effect of social network on job satisfaction and employee performance; Zaman and Chowdhury (2012) have analyzed the present status, future prospects and challenges of technology driven banking; Alam (2013) have investigated the future prospect of ' $3 \mathrm{G}$ ' network in Bangladesh; Rahaman, Ullah and Shafayet (2013) have explored the factors that are influencing Facebook privacy awareness of Bangladeshi undergraduate university students. But none of them have investigated the impacts of the use of social networking sites on Bangladeshi students' academic results in any of their aforementioned studies except, Asad, Mamun \& Clement (2012) who have surveyed the effect of social networking sites to the lifestyles of teachers and students; and Mafiz, Ismail, and Bhuyan (2011) who have assessed the effects of socio-economic, demographic and internet exposure factors on school performance among selected high school students.

But yet in the context of Bangladesh, there has hardly been any study which significantly has set forth the potential impacts of using of social networking sites on students' academic results in different college and university settings. Hence, to plug this gap in the literature, this study primarily attempts to identify whether the use of social networking sites by university students has any tendency to influence their academic results or not in the context of Bangladesh. In particular, importance of this issue is significantly connected to those streams of research which identifies higher education as a key component to a country remaining globally competitive and declining academic performance can have long-term consequences for both, society and the individual, in terms of overall quality of life (Down, 2009; Phusavat, Ketsarpong, Ooi, \& Shyu, 2012). 
TABLE 1

EFFECTS OF SOCIAL NETWORKING SITES

\begin{tabular}{|l|l|l|l|}
\hline \multicolumn{2}{|c|}{ To Students } & \multicolumn{2}{c|}{ To Teachers } \\
\hline Positive Effects & Negative Effects & Positive Effects & Negative Effects \\
\hline $\begin{array}{l}\text { Sharing homework, } \\
\text { information, } \\
\text { resources or ideas }\end{array}$ & $\begin{array}{l}\text { Failure to meet } \\
\text { study targets }\end{array}$ & $\begin{array}{l}\text { Share information } \\
\text { and resources with } \\
\text { students }\end{array}$ & $\begin{array}{l}\text { Devotes little } \\
\text { time to attend to } \\
\text { students class } \\
\text { related problems }\end{array}$ \\
\hline $\begin{array}{l}\text { Communicating to } \\
\text { teachers }\end{array}$ & $\begin{array}{l}\text { Poor performance } \\
\text { (lower grades) }\end{array}$ & $\begin{array}{l}\text { Learn how social } \\
\text { networking can be } \\
\text { incorporated into } \\
\text { teaching }\end{array}$ & $\begin{array}{l}\text { Reduction in } \\
\text { face-to-face } \\
\text { human contact } \\
\text { due to SNS }\end{array}$ \\
\hline $\begin{array}{l}\text { General group } \\
\text { discussion and } \\
\text { exchanging ideas }\end{array}$ & $\begin{array}{l}\text { Paying more } \\
\text { attention towards } \\
\text { SNS than utilizing } \\
\text { this time for their } \\
\text { studies }\end{array}$ & $\begin{array}{l}\text { Creates student } \\
\text { groups to collaborate } \\
\text { on projects }\end{array}$ & $\begin{array}{l}\text { Reducing the } \\
\text { time of doing } \\
\text { research to } \\
\text { improve on your } \\
\text { profession }\end{array}$ \\
\hline $\begin{array}{l}\text { Assignment } \\
\text { preparation and } \\
\text { argument }\end{array}$ & $\begin{array}{l}\text { Missing classes } \\
\text { due to SNS }\end{array}$ & $\begin{array}{l}\text { Increases teachers } \\
\text { availability to } \\
\text { tudents outside } \\
\text { school hours }\end{array}$ & $\begin{array}{l}\text { Affects } \\
\text { profession } \\
\text { reputation and } \\
\text { career }\end{array}$ \\
\hline $\begin{array}{l}\text { Communication } \\
\text { among students and } \\
\text { their instructors, } \\
\text { following } \\
\text { announcements } \\
\text { about classes and } \\
\text { courses }\end{array}$ & $\begin{array}{l}\text { Reduction in face } \\
\text { to face human } \\
\text { contact }\end{array}$ & $\begin{array}{l}\text { Enables research } \\
\text { through the } \\
\text { exchange of } \\
\text { different materials }\end{array}$ & $\begin{array}{l}\text { Causes stress and } \\
\text { affects your } \\
\text { health }\end{array}$ \\
\hline Source: Asad, at and & & & \\
\hline
\end{tabular}

Source: Asad, et al., 2012.

\subsection{Social Networking Sites (SNSs)}

Social networking sites, henceforward SNSs, specifically refer to those Internet-based services that: promote online social interaction between two or more persons within a bounded system for the purposes of friendship, meeting other persons, and/or exchanging information; contains a functionality that lets users create public or semi-public personal profile pages that contain information of their own choosing; articulates a list of other users with whom they share a connection, and thus serves as a mechanism to communicate with other users; and contains mechanisms that allow users to search for other users according to some specific criteria (Boyd, \& Ellison, 2007, 2008; EU, 2009; Zwart, Lindsay, Henderson, \& Phillips, 2011). 


\subsection{Global Consumption or Use of SNSs}

Since 2000, overall internet use and the use of SNSs have grown significantly (Pew, 2009). In terms of membership and daily usage, more recent estimates show that Facebook has 1.19 billion monthly active users; LinkedIn over 100 million members; Twitter having over 177 million tweets per day; and YouTube having over 3 billion views each day (Chen, \& Bryer, 2012). Amongst these, the overwhelmingly more popular SNS is Facebook (Gonzalez, 2009) which has, as of September 2013, 727 million daily active users on average and there are approximately 874 million monthly active users who used Facebook mobile products (https://newsroom.fb.com/Key-Facts). Additionally, in terms of overall popularity regarding usage, one recent survey conducted by the Pew Research Center found that Facebook is the most used (92\%), followed by MySpace (29\%), then LinkedIn (18\%), Twitter (13\%), and other SNSs (10\%) (Hampton, Sessions-Goulet, Rainie, \& Purcell, 2011). In terms of age, approximately $61 \%$ of teens, aged between 12 and 17, utilize SNSs to send messages to their friends on a regular basis (Lenhart, 2009). Besides, the use of SNSs has been repeatedly found to be the highest among those between the ages of 18 and 29 (Rainie, 2011) and the fastest growing segment utilizing SNSs since 2008 has been among those age 35 and older (Hampton et al., 2011, p. 8). Furthermore, In terms of gender, it has been found that women more than men tend to utilize SNSs to communicate and exchange information (Hampton et al., 2011).

\subsection{Rewards and Drawbacks of Using SNSs}

In general, benefits typically associated with the use of SNSs have included: encouraging greater social interaction via electronic mediums; providing greater access to information and information sources; encouraging creativity among and between individuals and groups; creating a sense of belonging among users of common social media tools; providing more choices to promote engagement among different individuals and groups; reducing barriers to group interaction and communications such as distance and social/economic status; and increasing the technological competency levels of frequent users of SNSs (Connolly, 2011; Rosen, 2011; and Zwart, et al., 2011). Conversely, potential risks or drawbacks identified with the use of SNSs include risks of psychological disorders and health problems such as social isolation, anxiety, depression, time mismanagement, poor eating habits, and lack of physical exercise; amplified 
short attention spans and subverted higher-order reasoning skills such as concentration, persistence, and analytical reasoning among frequent users of SNSs; a tendency to overestimate one's ability to multi-task and manage projects; and technology being seen as a substitute for the analytical reasoning process (Anderson, \& Rainie, 2012; Brenner, 1997; Connolly, 2011; Kraut, Patterson, Lundmark, Kiesler, Mukophadhyay, \& Scherlis, 1998; Rosen, 2011; Young, 1996; and Zwart, et al.,, 2011).

\subsection{Impacts of Using SNSs on Students}

Long since, there has also been considerable discussion regarding the frequent use of different SNSs by students and the possible effect of its tools (e.g., Facebook, MySpace, Twitter, Xanga, Friendster) on students' academic performance (Connolly, 2011; Hargittai \& Hsieh, 2010; Karpinski \& Duberstein, 20009). Regarding academic settings, Lenhart in 2009 and later, Anderson \& Rainie in 2012 have mentioned that use of internet has wide spread implications particularly for the areas of education (e.g., the identification and use of compatible teaching methods, the design and implementation of complimentary curriculum decisions, and the design of non-classroom educational assignments); communications (e.g., the identification of appropriate channels to exchange educational information among individuals); and economics (e.g., the allocation of public financial resources towards educational and social services activities, and the creation of future business opportunities) (Anderson, \& Rainie, 2012; Chen, \& Bryer, 2012). But widely divergent studies in the field of higher education (e.g. Colleges and Universities) have engendered an assortment of findings. Some researchers, studying the impact of SNSs on college students' academic performance, found a negative effect; that is, higher usage typically leading to lower academic performance as measured by grades (Canales, Wilbanks, \& Yeoman, 2009; Karpinski, \& Duberstein, 2009; Rouis, Limayem, \& Salehi-Sangari, 2011; Stollak, Vandenberg, Burklund, \& Weiss, 2011; Wang, Chen, \& Liang, 2011). At Alfred University, 50\% of students interviewed after dismissal for academic failure listed excessive Internet usage as a reason for their problems ("On Line," 1996). Furthermore, by asking students that why they did not put more effort into academic work, Yazedjan et al. in 2008 have found SNSs' distraction as a regular explanation. Other researchers studying this same issue found either no-to-little relationship between the use of SNSs and student academic performance (Ahmed \& Qazi, 2011; Hargittai \& Hsieh, 2010; Kolek 
and Saunders, 2008), or actually an increase in student academic performance (Junco, Heibergert, \& Loken, 2011; Pasek, More, \& Hargittai, 2009; Rizzuto, LeDoux, \& Hatala, 2009). Among these studies, Madge, et al. in 2009 found that SNSs are mainly used to keep up with social aspects of college life and it is a part of most students' daily routine. Kubey, Lavin, \& Barrows have found in their study that recreational Internet use is strongly correlated with impaired academic performance (Kubey, Lavin, \& Barrows, 2001).

\subsection{Use of SNSs in the Academic Sector of Bangladesh}

By studying 137 Private university students, Mostafa (2011) has found in his study that, 56.2 percent students used the internet for educational purposes, 15.3 percent for research purposes, 10.2 percent for communication purposes, 16.8 percent for entertainment purposes and remaining 1.5 percent indicated used it for other purposes. Mostafa (2011) also has identified in his study that, most $(82.5 \%)$ of the students responded that internet can play a significant role in the field of education. Mafiz, Ismail and Bhuyan (2011) have studied the impact of socio-economic, demographic and internet exposure factors on school performance among 10 grade students of Nilkhet High School and hence, they have found that, overall $80.5 \%$ out of 87 students were exposed to internet, and among these internet users, $79.3 \%$ had Facebook account. They also have found that, majority of the students (50.6\% out of 87 ) used internet for entertainment, $20.7 \%$ used internet for educational purposes (Mafiz, Ismail and Bhuyan, 2011). Besides, Asad, et al. (2012), by studying 200 respondents comprised of 100 teachers and 100 students, have found in their study that, Facebook is used by $90 \%$ students and $82.1 \%$ teachers; $47 \%$ of students and $57.1 \%$ of teachers have logged on in to these SNSs at least once in a day; $87 \%$ students and $96.4 \%$ teachers have used their computers to access internet; $22 \%$ students have used mobile phone and $36.9 \%$ teachers have used the same device for accessing it

In terms of different devices to access the internet and different places from where the internet has been accessed, they have found $87 \%$ have used computers, $22 \%$ used their mobile phones and $2 \%$ used other devices; and majority (52\%) have accessed the internet from their hostels, $43 \%$ from computer laboratory, $8 \%$ from their classes and $3 \%$ from the library respectively. Besides, in terms of the duration of use, Asad, et al. (2012) have further reporter in their study that majority $(47 \%)$ of the students have indicated that they logged in once in a day, 
$36 \%$ spent $2-5$ times a day, $10 \%$ spent a couple of hours and only $7 \%$ were always logged on (Asad, et al., 2012).

However, by utilizing non-parametric statistics (Chi square test), both of these two aforesaid studies have significantly concluded that, (i) the school performance measured by grade of the students was significantly related with the work on internet (Mafiz, Ismail and Bhuyan, 2011), and (ii) students' poor performance (lower grades) is one of the negative effects of using SNSs (Asad, et al., 2012).

\subsection{Research Gap}

Although the frequency of using different SNSs is well documented in the literature (See Asad, et al., 2012; Chen, \& Bryer, 2012; Gonzalez, 2009; Hampton et al., 2011; Lenhart, 2009; Mafiz, Ismail and Bhuyan, 2011; Pew, 2009; Rainie, 2011), none of the aforesaid studies and other previous studies have assessed the quantity of active SNSs that each student may have and its association with that student's academic results. Besides, impacts of both, the quantity of installed mobile messaging applications and its frequency of use, on students' academic results have not been explored yet in Bangladesh. Similarly, in terms of variance, comparative predictability of this two types of social networking tools regarding the academic results of students have not been shown in any research study. Hence, this study has tried to set forth the prospective impacts of SNSs on the academic result of Bangladeshi university students, especially undergraduate students, throughout following queries:

a) How many active social networking sites (SNSs) does each student have and which one among these accounts is most frequently used by them?

b) How much time in any particular day is spent by the students in these social networking accounts?

c) How many mobile messaging applications does each student have installed in their mobile phones and which one among these installed mobile messaging applications is most frequently used by the students?

d) How much time in any particular day is spent by the students in these installed mobile messaging applications?

e) What is the average result of each student in last two semesters?

f) To what extent, the use of SNSs can predict each student's achieved average result? 
g) How much variance in each student's achieved average result in last two semesters can be explained by their use of SNSs and mobile messaging applications?

h) Between these both habits, using SNSs and using mobile messaging applications, which one is the best predictor of students achieved average results in last two semesters?

i) If we control for the possible effect of some additional demographic independent variable, are these both independent factors, Exploitation of SNSs and Exploitation mobile messaging applications, still be able to predict a significant amount of variance in the students' achieved average results in last two semesters?

\section{METHODOLOGY OF THE STUDY}

\subsection{Research Design}

Most appropriate type of research design for this study was causal research because, as kind of conclusive research, it deals with the potential cause and effect relationship among identified variables in any study.

\subsection{Operationalization}

\subsubsection{Independent Variables}

This study consists of two independent variables, namely- (i) Social Networking Sites (SNSs) and (ii) Mobile Messaging Applications (MMAs), and thus had looked for their quantity as well as frequency of use.

\subsubsection{Social Networking Sites (SNSs)}

This study defined social networking sites as "technologies that facilitate social interaction, make possible collaboration, and enable deliberations across stakeholders" (Bryer \& Zavattaro, 2011, p. 327; Chen, \& Bryer, 2012, p. 88). To assess the quantity of registered active SNSs that each student may possibly have, a checklist containing the name of 15 different but most popular SNSs was developed (i.e. Facebook, Twitter, Tagged, MySpace, Pinterest, Google Plus+, Meetup, Mylife, etc.). After that, all the responding 
students were asked to ensure from the given list that whether or not they are using one or more than one of those SNSs. Moreover, it had been compassionately assumed in this study that, some students might use some other similar sites which was not enlisted and thus, they were asked to specify the name of those unlisted SNSs as well as an additional 'don't have' option was inserted for those students who didn't really have registered in any such types of SNSs yet. Besides, students were asked to mention from the aforesaid check list of SNSs that which one they used mostly along with their average tenure of using it in any given day.

\subsubsection{Mobile Messaging Applications (MMAs)}

This study have defined 'Mobile Messaging Applications', hereafter MMAs, as instant messaging technologies which are mobile phone friendly in nature and which may utilize either online or offline or both type of connectivity for pursuing social affiliation effectively and efficiently. Thus, a check list, containing the names of 10 most popular mobile messaging applications, was offered to the responding students to confirm that how many of these applications they had installed in their mobile phones. Additionally, students were also inquired to specify if they used any other similar MMAs which were not procured in that check list, as well as, an additional 'Incompatibility' clause was added for those students who either didn't have any mobile phone or the phone they have has an incompatibility to install and use such types of mobile messaging application. Afterward students were asked to mention which one among those aforementioned MMAs they mostly use in conjunction with their average tenure of using such applications in any given day. Also, the numbers of registered active SNSs as well as the number of installed

mobile messaging application reported by individual respondents were coded and then grouped into the following five (05) categories like this: 


\section{Code Used}

0
1
2
3
4
5

\author{
Defined Categories \\ Don't / Can't Use \\ Trivial Users \\ Slightly Heavy Users \\ Heavy Users \\ Overly Heavy Users \\ Unusually Heavy Users
}

\author{
Range of Registered Active \\ Social Networking Accounts \\ 0 \\ $01-02$ \\ $03-04$ \\ $05-06$ \\ $07-08$ \\ 9 and above
}

\subsubsection{Dependent Variable:}

Students' achieved average results in last two semesters were the one and only dependent variable of this study. To ease the generalization and estimation of student, they were asked to mention their results of last two semesters in the format of 'Grade Point Average GPA)'. Next, individual respondent's reported results of last two semester were averaged simply by calculating the sum total of those two results and then dividing that sum total (Result of Semester One + Result of Semester Two) by the total numbers of results (02) reported by each students. Subsequently, their achieved average results in last two semesters was coded and then grouped into the following six (06) categories,

\section{Code Used}

1
2
3
4
5
6

Defined Categories

Weak Students

Below Average Students

Above Below Average Students

Average Students

Above Average Students

Well-built Students

\author{
Range of Achieved \\ Average Results \\ Less than 1.49 \\ $1.50-1.99$ \\ $2.00-2.49$ \\ $2.50-2.99$ \\ $3.00-3.49$ \\ 3.50 and Above
}

\subsection{Data extraction and analysis}

A random sample, constituted with 1250 Bangladeshi undergraduate students from different universities of Dhaka Metro Politian City, surveyed with a self administered structured questionnaire. The survey was conducted by the researchers themselves in the period April to July, 2013. To test whether the scales were reliable or not, the value of the Chronbach's alpha had been estimated and evaluated against the recommended standard by DeVellis (2003) who 
suggested that, ideally the Cronbach alpha coefficient of a scale should be above (0.7). As the number of items in all the scales in this study, 'Achieved average results', 'Use of SNSs' and 'Use of Mobile Messaging Applications', are much less (below 10), the inter-item correlations of these scales are also evaluated and reported according to the recommend optimal range of Briggs and Cheek (1986) ${ }^{\mathbf{i}}$. Besides, the 'Bivariate' correlation analysis was done by using 'Pearson Productmoment Correlation' to explore the relationships between dependent and independent variables, and the resulting relationships were interpreted according to the standards suggested by Cohen (1988) where ' $r=.10$ to .29 or $r=-.10$ to .29 ' stands for 'small'; ' $\mathrm{r}=.30$ to .49 or $\mathrm{r}=-.30$ to -.49 ' for 'medium' and ' $\mathrm{r}=.50$ to 1.0 or $\mathrm{r}=-.50$ to -1.0 ' for 'large' relationships. Decision of accepting or rejecting the null hypotheses was taken on the basis of consequential 'Significance' value and 'F' value calculated by the analysis of variance (ANOVA). After measuring the outliers, normality, and multi-colinearity, the standard multiple regression and sequential multiple regression analysis were conducted to find the answers of the remaining queries of this study.

\section{ANALYSIS}

\subsection{Sample Demographics}

After receiving the feedback, 68 fragmentary questionnaires were declined and 1182 feedbacks were retained for further processing which engendered 94.56\% response rate for this study. Among these 1182 respondents, $33.6 \%$ of the total respondents were female and $66.4 \%$ were male. The average age of those students were 21.40 years along with a standard deviation of 1.473, Standard error of mean .043 and 2.169 years of variance. Both the median and modal age were found to be 21 years which indicates a normal distribution. In terms of academic tenure in a 4 years undergraduate program, most $(46.4 \%)$ of the students were from the 1 st semester, $72.5 \%$ were in between 1 st to 3 rd year and $325(27.5 \%)$ respondents were found studying in the 4th year. And, as the categories of students were pre-coded, most $(53.6 \%)$ of the sampled students were found to be the Well-built Students of their universities, followed by $35.4 \%$ were above average students, $10.2 \%$ were average students and $1.2 \%$ were weak students to above the below average students (see APPENDIX 01.A, \& APPENDIX 01.B). 


\subsection{Reliability of Retrieved Response}

Table 2 below represents the calculated values of reliability analysis along with each scales' inter-item correlation matrix. It can be seen for the Table 2 that, the assessed Cronbach Aplha value of tudents' achieved academic results was 0.950 which is much higher than DeVellis's (2003) recommended of 0.70. From the same table, it can be observed that, though the calculated Aplha value (0.670) for students' use of SNSs and mobile messaging application is somewhat less than the recommended value of DeVellis (2003), their inter-item correlation (.575) is much higher than the recommend optimal range for the inter-item correlation of .2 to .4 by Briggs and Cheek (1986). Hence all scales developed for the study were internally consistent and also reliable.

TABLE 2

\section{RELIABILITY STATISTICS AND INTER-ITEM CORRELATION MATRIX}

\begin{tabular}{|c|c|c|c|c|c|c|}
\hline \multirow{2}{*}{$\begin{array}{l}\text { Name of the } \\
\text { Variables }\end{array}$} & \multicolumn{2}{|c|}{ Reliability Statistics } & \multirow{2}{*}{\multicolumn{4}{|c|}{ Inter-item Correlation Matrix }} \\
\hline & Cronbach's & $\begin{array}{l}\text { Cronbach's } \\
\text { Alpha Based }\end{array}$ & & & & \\
\hline \multirow{2}{*}{$\begin{array}{l}\text { Result of } \\
\text { Semester } 01\end{array}$} & \multirow{4}{*}{0.950} & \multirow{4}{*}{0.952} & & $\begin{array}{c}\text { Result } \\
01 \\
\end{array}$ & $\begin{array}{c}\text { Result } \\
02 \\
\end{array}$ & $\begin{array}{c}\text { Average } \\
\text { Result }\end{array}$ \\
\hline & & & $\begin{array}{c}\text { Result } \\
01\end{array}$ & 1.00 & .741 & .930 \\
\hline $\begin{array}{l}\text { Result of } \\
\text { Semester } 02\end{array}$ & & & $\begin{array}{c}\text { Result } \\
02\end{array}$ & .741 & 1.00 & .936 \\
\hline $\begin{array}{l}\text { Achieved } \\
\text { Average } \\
\text { Results }\end{array}$ & & & $\begin{array}{c}\text { Average } \\
\text { Results }\end{array}$ & .930 & .936 & 1.00 \\
\hline \multirow{2}{*}{$\begin{array}{l}\text { Hours Per } \\
\text { Week Spent } \\
\text { for SNSs }\end{array}$} & \multirow{3}{*}{0.670} & \multirow{3}{*}{.730} & & \multicolumn{2}{|c|}{ Use of SNSs } & $\begin{array}{c}\text { Use of } \\
\text { MMAs }\end{array}$ \\
\hline & & & $\begin{array}{l}\text { Use of } \\
\text { SNSs }\end{array}$ & \multicolumn{2}{|c|}{1.00} & .575 \\
\hline $\begin{array}{l}\text { Hours Per } \\
\text { Week Spent } \\
\text { for MMAs }\end{array}$ & & & $\begin{array}{l}\text { Use of } \\
\text { MMAs }\end{array}$ & \multicolumn{2}{|c|}{.575} & 1.00 \\
\hline
\end{tabular}




\subsection{The Quantity and Frequency of SNSs and MMAs Used by Bangladeshi Students}

In terms of registered active social networking accounts, this study had found that out of 1182 students, $77.7 \%$ were the 'Trivial Users' (having 01-02 active accounts), $12.4 \%$ were 'Slightly Heavy Users', 5.6\% had agreed that they 'Don't or Can't Use' such accounts and other categories had included the remaining $4.2 \%$ students. Moreover, Facebook were used by $88.5 \%$ students followed by Twitter 2.2\%, GooglePlus+ 1.2\%, 6.3\% did not have used any kind of SNSs and the remaining social networking sites mentioned in the list were used by $1.8 \%$ students (see APPENDIX 02.A, APPENDIX 03). Besides, by asking the responding students (excluding those $66(5.6 \%)$ respondents who were not using any SNSs) to mention their average daily use in the form of hours per day, it was found that, out of 1116 students, about 83.8\% (990) were using SNSs for maximum two and half hours (02.5 Hours) and only $10.7 \%$ students were using it more than 02.5 hours (see APPENDIX 02.B). Furthermore, in terms of the quantity of installed mobile messaging application, most of the student's (42\%) had reported that their mobile phone have an incompatibility issue to install and use it, followed by 31.7\% were the 'Trivial Users' (installed 01-02 mobile messaging applications), $12.8 \%$ were 'Slightly Heavy Users', 7.4\% were 'Heavy Users' and $6.1 \%$ were the other type of users. In terms of preferring mobile messaging applications, it was found that, $13.71 \%$ students preferred eBuddy, followed by $11 \%$ preffered NimBuzz, $6.85 \%$ MessageMe, 5\% Viber and WeChat, $4.91 \%$ Line, $4.48 \%$ TextNow, $4.06 \%$ whatsApp, 42\% students' mobile phones were mismatched to use such applications and the remaining 3\% students had preferred either HeyTell or Snapchat or other MMAs (see APPENDIX 02.A \& APPENDIX 03). And by asking students (of course, excluding those 496 students who were facing incompatibility to install and use MMAs) to reveal their average daily use of MMAs in terms of hours per day, this study found that, out of 686 students, a total of 860 (57.5\%) students was not using MMAs for more than 04 hours and only a few $(0.5 \%)$ students were using it more than 04 hours (see APPENDIX 02.B) in a day.

\subsection{Relationship of Students' Achieved Results with the Use of SNSs and MMAs}

Table 3 below shows the consequent coefficients of correlation analysis between the independent and dependent variables of this study. Thus, it can be 
observed from resulting correlation coefficients shown in Table 03 that, two independent variables, frequency of using SNSs (with $r=-0.807$ ) and frequency of using MMAs (with $r=-0.464$ ), have strong and inverse relationship with the dependent variable (students' achieved academic results). This finding was statistically significant because, in both cases, the identified $\mathrm{P}$ values were less than $0.05(\alpha=<0.05)$.

\section{TABLE 3}

\section{CORRELATION COEFFICIENTS DEPICTED}

\begin{tabular}{|l|c|c|c|}
\hline Items & Average Results & Use of SNSs & Use of MMAs \\
\hline Average Results & 1 & $-.807^{* *}$ & $-.464^{* *}$ \\
\hline Use of SNSs & $-.807^{* *}$ & 1 & $.515^{* *}$ \\
\hline Use of MMAs & $-.464^{* *}$ & $.515^{* *}$ & 1 \\
\hline \multicolumn{2}{|r}{ **. Correlation is significant at the 0.01 level (1-tailed). }
\end{tabular}

\subsection{Assessment of Normality and Outliers}

Normality was assessed by 'Normal Probability Plot of Regression Standardized Residuals' which is illustrated by Figure 01 below. Here it can be observed that points were positioned in a reasonably straight diagonal line from bottom left to top right indicating no major deviation from normality.

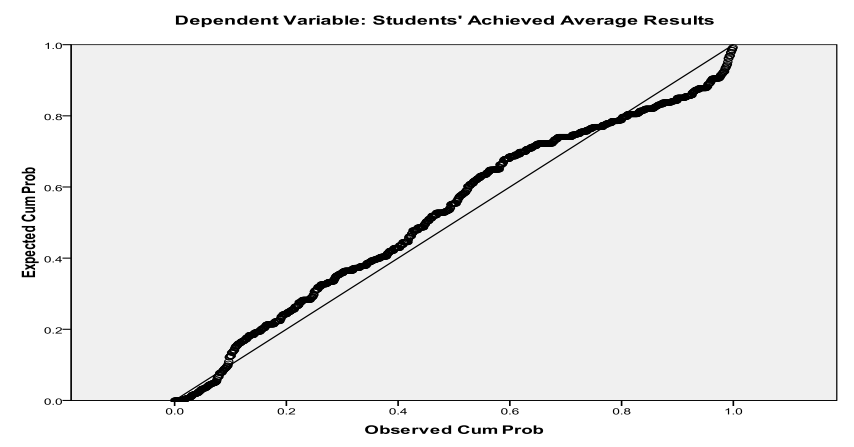

FIGURE 01: Normal P-P Plot of Regression Standardized Residual

Moreover, Tabachnick and Fidell (1996) defined outliers as cases that have a standard residual of more than 3.3 or less than -3.3. As shown in Figure 02 below, all the observed cases, except a few, were within this range. 


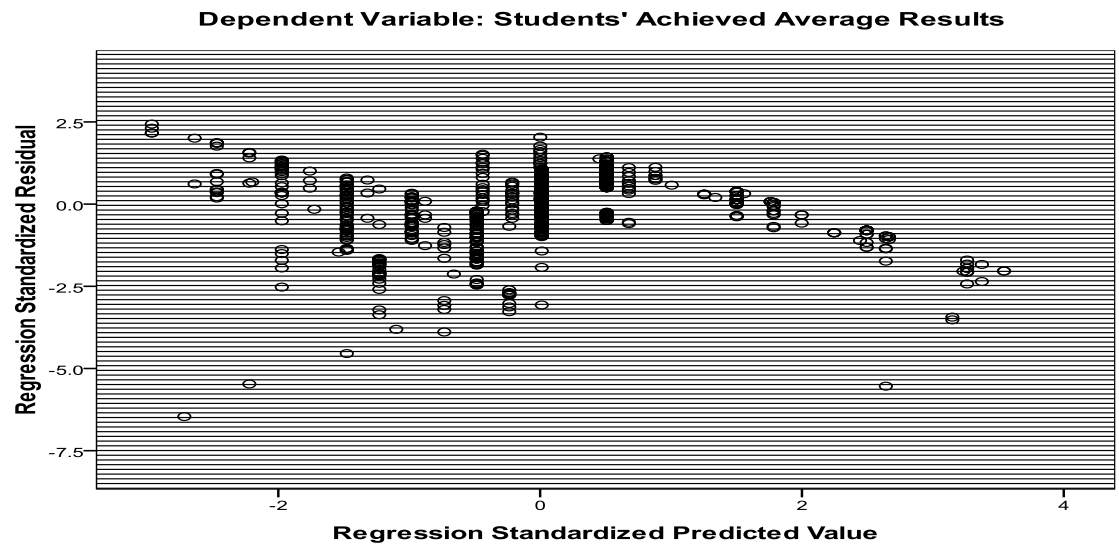

FIGURE 02: Scatterplot

Thus, to inspect the number of outliers, Mahalanobis Distance was compared against the recommended critical value which is shown in Table 4 below.

TABLE 4

RESIDUALS STATISTICS A

\begin{tabular}{|l|c|c|c|c|l|}
\hline & Minimum & Maximum & Mean & $\begin{array}{l}\text { Std. } \\
\text { Deviation }\end{array}$ & $\mathbf{N}$ \\
\hline Predicted Value & 1.76 & 6.68 & 5.42 & .597 & 1182 \\
\hline Std. Predicted Value & -6.123 & 2.119 & .000 & 1.000 & 1182 \\
\hline $\begin{array}{l}\text { Standard Error of Predicted } \\
\text { Value }\end{array}$ & .014 & .083 & .019 & .007 & 1182 \\
\hline Adjusted Predicted Value & 1.79 & 6.69 & 5.42 & .597 & 1182 \\
\hline Residual & -2.681 & .270 & .000 & .397 & 1182 \\
\hline Std. Residual & -6.749 & .681 & .000 & .999 & 1182 \\
\hline Stud. Residual & -6.765 & .681 & -.001 & 1.001 & 1182 \\
\hline Deleted Residual & -2.694 & .271 & .000 & .399 & 1182 \\
\hline Stud. Deleted Residual & -6.897 & .681 & -.002 & 1.006 & 1182 \\
\hline Mahal. Distance & .379 & 51.073 & 1.998 & 3.053 & 1182 \\
\hline Cook's Distance & .000 & .074 & .002 & .007 & 1182 \\
\hline Centered Leverage Value & .000 & .043 & .002 & .003 & 1182 \\
\hline
\end{tabular}

TABLE 4 Cont. 


\begin{tabular}{|l|c|c|c|c|c|}
\hline & Minimum & Maximum & Mean & $\begin{array}{l}\text { Std. } \\
\text { Deviation }\end{array}$ & N \\
\hline Predicted Value & 1.76 & 6.68 & 5.42 & .597 & 1182 \\
\hline Std. Predicted Value & -6.123 & 2.119 & .000 & 1.000 & 1182 \\
\hline $\begin{array}{l}\text { Standard Error of Predicted } \\
\text { Value }\end{array}$ & .014 & .083 & .019 & .007 & 1182 \\
\hline Adjusted Predicted Value & 1.79 & 6.69 & 5.42 & .597 & 1182 \\
\hline Residual & -2.681 & .270 & .000 & .397 & 1182 \\
\hline Std. Residual & -6.749 & .681 & .000 & .999 & 1182 \\
\hline Stud. Residual & -6.765 & .681 & -.001 & 1.001 & 1182 \\
\hline Deleted Residual & -2.694 & .271 & .000 & .399 & 1182 \\
\hline Stud. Deleted Residual & -6.897 & .681 & -.002 & 1.006 & 1182 \\
\hline Mahal. Distance & .379 & 51.073 & 1.998 & 3.053 & 1182 \\
\hline Cook's Distance & .000 & .074 & .002 & .007 & 1182 \\
\hline Centered Leverage Value & .000 & .043 & .002 & .003 & 1182 \\
\hline a. Dependent Variable: Students' Achieved Average Results \\
\hline
\end{tabular}

In this study, the critical values for evaluating Mahalanobis distance (see Tabachnick and Fidell, 2007) was 13.82 because it had two independent variables only. Table 04 above represents the results of residual statistics from where, under the column headed 'Maximum', it can be observed that the Mahalanobis Distance for this study was 51.073 which was much higher than the critical value (13.82), and 13 specific cases with the largest Mahalanobis Distance were responsible for this deviation. However, instead of removing those 13 cases, they were considered to be kept because the maximum value for Cook's Distance (see Table 04: Residual Statistics) of this study was .074, suggesting no major problemi .

\subsection{Multi-colinearity Test}

To assess the degree of multi-colinearity, 'Tolerance' and 'VIF' (variation inflation factor) were used (Stapelton, 1995) in this study. Table 05 represents the outputs of 'Collinearity Diagnostics' which was actually performed as a part of standard multiple regression analysis. Here the values given in the column headed 'Tolerance' was calculated by the formula: 1-R2 for each variable. Standardized Regression assumes that, if this value is very low (near 0), then there is a possibility of multi-colinearity. From Table 05 below, it can be 
observed that the tolerance values for the two independent factors were identical and quite respectable $(\mathrm{SNSs}=.734, \mathrm{MMAs}=.734)$ in this study, and the VIF values for those two specific factors were 1.362. Hence, it was not only confirmed that this study did not violated the assumption of multi-colinearity and but also no problem of multi-colinearity appears to be present in the study.

TABLE 5

\section{COEFFICIENTS OF STUDENTS' ACHIEVED AVERAGE RESULTS}

\begin{tabular}{|c|c|c|c|c|c|c|c|c|}
\hline \multirow{2}{*}{\multicolumn{2}{|c|}{ Model }} & \multicolumn{2}{|c|}{$\begin{array}{l}\text { Unstandardized } \\
\text { Coefficients }\end{array}$} & \multirow{2}{*}{ 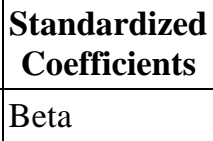 } & & \multirow{2}{*}{ Sig. } & \multicolumn{2}{|c|}{$\begin{array}{l}\text { Collinearity } \\
\text { Statistics }\end{array}$} \\
\hline & & B & Std. Error & & & & Tolerance & VIF \\
\hline & (Constant) & 6.681 & .028 & & 242.494 & .000 & & \\
\hline & Use of SNSs & -.911 & .022 & -.795 & -42.261 & .000 & .734 & 1.362 \\
\hline & Use of MMAs & -.041 & .011 & -.069 & -3.668 & .000 & .734 & 1.362 \\
\hline
\end{tabular}

\subsection{Assessment of Null Hypotheses}

Table 6 below represents the outcome of analysis of variance (ANOVA) as a part of standard multiple regression analysis.

TABLE 6

\section{ANALYSIS OF VARIANCE (ANOVA B)}

\begin{tabular}{|c|c|c|c|c|c|c|}
\hline & Model & Sum of Squares & df & Mean Square & $\mathbf{F}$ & Sig. \\
\hline \multirow[t]{3}{*}{1} & Regression & 421.104 & 2 & 210.552 & 1332.608 & $.000 \mathrm{a}$ \\
\hline & Residual & 186.104 & 1179 & .158 & & \\
\hline & Total & 607.208 & 1181 & & & \\
\hline
\end{tabular}

In Table 6, mentioned above, the $\mathrm{F}$ value was derived from dividing the Mean Square Model (210.552) by the Mean Square Residual (0.158), which was equal to 1332.608. Consequently, the $\mathrm{P}$ value associated with this $\mathrm{F}$ value, shown under the column headed 'Sig.', was less than 0.001. Thus P and F value depicted in Table 06 above indicates that independent variables (SNSs and MMAs) of this study reliably predicted the dependent variable (Student's Achieved Average Results) along with strong evidence against the null hypothesis. 


\subsection{Evaluation of the Model}

Standard Multiple Regression analysis was conducted to evaluate the model used in this study. The column's value in Table 7 under the heading 'Adjusted R Square' indicates $69.3 \%$ (0.693 X 100) of variance in Student's Achieved Average Results.

TABLE 7

MODEL SUMMARY B

\begin{tabular}{|l|c|c|c|c|}
\hline Model & $\mathrm{R}$ & R Square & Adjusted R Square & Std. Error of the Estimate \\
\hline 1 & $.833 \mathrm{a}$ & .694 & .693 & .397 \\
\hline
\end{tabular}

More precisely, the 'Beta Value' of independent factors under the column 'Standardized Coefficients' in Table 4 represents which of the factors included in this model contributed to the prediction of dependent variable. The largest standardized beta coefficient found in this study was -0.795 which stands for 'Use of SNSs'. It represents that, when the variance explained by all other variables in this model was controlled for, this variable (Use of SNSs) made the most strongest and unique contribution to explain the dependent variable (Students' Achieved Average Results) significantly ( $\mathrm{Sig}=.000$ ). For further query, 'Sequential Multiple Regression' analysis was conducted to understand that, if we control the possible effect of 'Gender', 'Age', 'Marital Status', 'Academic Year and Semester' as additional independent factors, whether or not, the main set of independent variables (Use of SNSs and MMAs) still be able to predict a significant amount of variance in 'Students' Achieved Average Results'. As demonstrated in Table 08 below, it can be realize that, after entering the additional factors (Gender, Marital Status, Age, Academic Year and Semester) into the 'Block 1', the overall model (Model 1) had explained 4.4\% variance in students' achieved average results. Next, after entering all the assumed independent factors together (Gender, Marital Status, Age, Academic Year, Semester, Use of SNSs and MMAs) into the 'Block 2', engendered 'Model 2 ' as a whole had explained $69.8 \%$ variance. It means that, if the effects of 'Gender', 'Age', 'Marital Status', 'Academic Year' and 'Semester' were statistically controlled for, 'Use of Social networking sites (SNSs)' and 'Use of Mobile Messaging Applications (MMAs)' together can explain an additional $65 \%$ variance in 'Students' Achieved Average Results' in the context of 
Bangladesh significantly (see Table 08 where R Square Change $=.650$, F change $=1264.909, \mathrm{p}<.001)$.

TABLE 8

MODEL SUMMARY OF THE SEQUENTIAL MULTIPLE REGRESSION

\begin{tabular}{|c|c|c|c|c|c|c|c|c|c|}
\hline \multirow[b]{2}{*}{ Model } & \multirow[b]{2}{*}{$\mathbf{R}$} & \multirow[b]{2}{*}{$\begin{array}{c}\mathbf{R} \\
\text { Square }\end{array}$} & \multirow{2}{*}{$\begin{array}{c}\text { Adjusted } \\
\text { R } \\
\text { Square }\end{array}$} & \multirow{2}{*}{$\begin{array}{c}\text { Std. } \\
\text { Error } \\
\text { of the } \\
\text { Estimate }\end{array}$} & \multicolumn{5}{|c|}{ Change Statistics } \\
\hline & & & & & $\begin{array}{l}\text { R Square } \\
\text { Change }\end{array}$ & $\begin{array}{l}\mathrm{F} \\
\text { Change }\end{array}$ & df1 & df2 & $\begin{array}{l}\text { Sig. F } \\
\text { Change }\end{array}$ \\
\hline 1 & $.219 a$ & .048 & .044 & .701 & .048 & 11.856 & 5 & 1176 & .000 \\
\hline 2 & $.836 b$ & .698 & .696 & .395 & .650 & 1264.909 & 2 & 1174 & .000 \\
\hline
\end{tabular}

a. Predictors: (Constant), Semester, Academic year, Gender, Marital Status, Age

b. Predictors: (Constant), Semester, Academic year, Gender, Marital Status, Age, Use of MMAs, Use of SNSs.

c. Dependent Variable: Achieved Average Results

TABLE 9

COEFFICIENTSA OF FACTORS CONTRIBUTING IN MODEL 1 \& MODEL 2

\begin{tabular}{|c|c|c|c|c|c|c|}
\hline & \multirow[t]{2}{*}{ Model } & \multicolumn{2}{|c|}{$\begin{array}{l}\text { Unstandardized } \\
\text { Coefficients }\end{array}$} & \multirow{2}{*}{\begin{tabular}{|l|}
$\begin{array}{c}\text { Standardized } \\
\text { Coefficients }\end{array}$ \\
Beta
\end{tabular}} & \multirow[t]{2}{*}{$\mathbf{t}$} & \multirow[t]{2}{*}{ Sig. } \\
\hline & & B & Std. Error & & & \\
\hline & (Constant) & 5.606 & .359 & & 15.611 & .000 \\
\hline & Respondents Gender & .112 & .045 & .074 & 2.469 & .014 \\
\hline \multirow{3}{*}{1} & Respondents Age & -.014 & .016 & -.029 & -.897 & .370 \\
\hline & Marital Status & -.086 & .062 & -.041 & -1.393 & .164 \\
\hline & Academic year & .116 & .022 & .170 & 5.369 & .000 \\
\hline & Semester & -.107 & .028 & -.111 & -3.843 & .000 \\
\hline \multirow{8}{*}{2} & (Constant) & 6.878 & .204 & & 33.665 & .000 \\
\hline & Respondents Gender & -.030 & .026 & -.020 & -1.146 & .252 \\
\hline & Respondents Age & -.007 & .009 & -.015 & -.815 & .416 \\
\hline & Marital Status & -.048 & .035 & -.022 & -1.361 & .174 \\
\hline & Academic year & .044 & .012 & .064 & 3.553 & .000 \\
\hline & Semester & -.024 & .016 & -.025 & -1.493 & .136 \\
\hline & Use of SNSs & -.902 & .022 & -.787 & -41.510 & .000 \\
\hline & Use of MMAs & -.039 & .011 & -.067 & -3.516 & .000 \\
\hline
\end{tabular}

Additionally, the 'Beta Value' of independent factors, shown under the column 'Standardized Coefficients' in Table 09 above, represents which of the factors included in the Model 2 had contributed to the prediction of dependent 
variable as well as the degree of their individual significance of unique contribution. By scanning the 'Sig. column', it can be unfolded that, out of seven independent factors, only three factors had contributed statistically ( $p$ value less than .05). As said by the importance those were: Use of Social networking sites (beta $=-0.787$ ), Use of Mobile Messaging Application (beta $=-0.067$ ), and Academic Year $($ beta $=0.064)$.

\section{CONCLUSIVE GENERALIZATION OF ANALYSES}

In the context of Bangladesh, this study conclusively generalizes according to the analyzed findings that, approximately $77 \%$ of Bangladeshi university students do not use more than two social networking sites (SNSs); 83.8\% students have mentioned up to 2.5 hours per day as maximum tenure of using SNSs; and Facebook is the most frequently preferred SNSs among the other popular SNSs. In terms of using different mobile messaging applications (MMAs), 'eBuddy' and 'NimBuzz' are found commonly used by Bangladeshi Students and most of the students are using these messaging applications up to 04 hour in a day. As consequences, it has significantly been found in this study that, university students' academic results are inversely influenced by their use of different social networking sites and mobile messaging application. That is, the more a student gets involved in using such SNSs and MMAs, the more lower grades might be achieved by them. It has been suggested based on the aforementioned findings that, students use of SNSs and MMAs must be closely monitored by their parents and teachers, and if possible, such use should be controlled after a certain extent to lower the possible distractions engendering from it and hence, uplifting their academic performance.

\section{CONSTRAINTS OF THIS STUDY AND FUTURE RESEARCH IMPLICATIONS}

By scrutinizing the post works on how the social networking sites affects the students, this study has attempted to merge the existing gap within the literature in the context of Bangladesh and hence, has presented some statistically significant information on it. But, caused by the time and funding constraints, this study could not conduct any inter-sector and intra-sector analysis to validate its findings and thus its replicability and generalizability, until now, are required to be tested. Thus, it proposes to the further comprehensive research studies to incorporate all of those excluded aspects. 
APPENDIX 1.A

DEMOGRAPHIC CHARACTERISTICS OF SAMPLE

\begin{tabular}{|c|c|c|c|}
\hline Demographic Factors & Frequency & Percent & $\begin{array}{c}\text { Cumulative } \\
\text { Percent }\end{array}$ \\
\hline \multicolumn{4}{|l|}{ Gender } \\
\hline Male & 785 & 66.4 & 66.4 \\
\hline Female & 397 & 33.6 & 100.0 \\
\hline Total & 1182 & 100.0 & \\
\hline \multicolumn{4}{|l|}{ Age } \\
\hline 17 & 2 & .2 & .2 \\
\hline 18 & 14 & 1.2 & 1.4 \\
\hline 19 & 92 & 7.8 & 9.1 \\
\hline 20 & 218 & 18.4 & 27.6 \\
\hline 21 & 329 & 27.8 & 55.5 \\
\hline 22 & 245 & 20.7 & 76.2 \\
\hline 23 & 185 & 15.7 & 91.9 \\
\hline 24 & 75 & 6.3 & 98.2 \\
\hline 25 & 20 & 1.7 & 99.9 \\
\hline 26 & 1 & .1 & 100.0 \\
\hline Total & 1181 & 99.9 & \\
\hline \multirow[t]{2}{*}{ System } & 1 & .1 & \\
\hline & 1182 & 100.0 & \\
\hline \multicolumn{4}{|l|}{ Year } \\
\hline 1st Year & 206 & 17.4 & 17.4 \\
\hline 2nd Year & 242 & 20.5 & 37.9 \\
\hline 3rd Year & 409 & 34.6 & 72.5 \\
\hline 4th Year & 325 & 27.5 & 100.0 \\
\hline Total & 1182 & 100.0 & \\
\hline Demographic Factors & Frequency & Percent & $\begin{array}{c}\text { Cumulative } \\
\text { Percent } \\
\end{array}$ \\
\hline \multicolumn{4}{|l|}{ Semester } \\
\hline 1 st Semester & 549 & 46.4 & 46.4 \\
\hline 2nd Semester & 427 & 36.1 & 82.6 \\
\hline 3rd Semester & 206 & 17.4 & 100.0 \\
\hline Total & 1182 & 100.0 & \\
\hline
\end{tabular}




\begin{tabular}{|c|c|c|c|}
\hline \multicolumn{4}{|l|}{ Category of Students } \\
\hline Weak Students & 1 & .1 & .1 \\
\hline Below Average Students & 2 & .2 & .3 \\
\hline $\begin{array}{c}\text { Above the Below Average } \\
\text { Students }\end{array}$ & 6 & .5 & 10.9 \\
\hline Average Students & 120 & 10.2 & 46.4 \\
\hline Above Average Students & 419 & 35.4 & 100.0 \\
\hline Well-built Students & 634 & 53.6 & \\
\hline Total & 1182 & 100.0 & \\
\hline
\end{tabular}

APPENDIX 1.B

DEMOGRAPHIC STATISTICS

\begin{tabular}{|l|c|c|c|}
\hline & Semester & $\begin{array}{c}\text { Respondents } \\
\text { Age }\end{array}$ & Academic year \\
\hline Mean & 1.71 & 21.40 & 2.72 \\
\hline Std. Error of Mean & .022 & .043 & .031 \\
\hline Median & 2.00 & 21.00 & 3.00 \\
\hline Mode & 1 & 21 & 3 \\
\hline Std. Deviation & .745 & 1.473 & 1.049 \\
\hline Variance & .555 & 2.169 & 1.100 \\
\hline Minimum & 1 & 17 & 1 \\
\hline Maximum & 3 & 26 & 4 \\
\hline
\end{tabular}


APPENDIX 2.A

QUANTITY OF ACTIVE SOCIAL NETWORKING SITES (SNSS) AND INSTALLED MOBILE MESSAGING APPLICATIONS (MMAS)

\begin{tabular}{|c|l|c|c|c|c|c|c|}
\hline \multirow{2}{*}{ Quantity } & \multirow{2}{*}{$\begin{array}{c}\text { Students } \\
\text { Category }\end{array}$} & \multicolumn{3}{|c|}{$\begin{array}{c}\text { No. of Registered Active } \\
\text { SNSs }\end{array}$} & \multicolumn{3}{|c|}{ No. of Installed MMAs } \\
\cline { 3 - 7 } & Frequency & Percent & $\begin{array}{c}\text { Cumulative } \\
\text { Percent }\end{array}$ & Frequency & Percent & $\begin{array}{c}\text { Cumulative } \\
\text { Percent }\end{array}$ \\
\hline 0 & $\begin{array}{l}\text { Don't / Can't } \\
\text { Use }\end{array}$ & 66 & 5.6 & 5.6 & 496 & 42.0 & 42.0 \\
\hline $01-02$ & Trivial Users & 919 & 77.7 & 83.3 & 375 & 31.7 & 73.7 \\
\hline $03-04$ & $\begin{array}{l}\text { Slightly Heavy } \\
\text { Users }\end{array}$ & 147 & 12.4 & 95.8 & 151 & 12.8 & 86.5 \\
\hline $05-06$ & Heavy Users & 45 & 3.8 & 99.6 & 88 & 7.4 & 93.9 \\
\hline $07-08$ & $\begin{array}{l}\text { Overly Heavy } \\
\text { Users }\end{array}$ & 5 & .4 & 100.0 & 50 & 4.2 & 98.1 \\
\hline 09 and & $\begin{array}{l}\text { Unusually } \\
\text { Above }\end{array}$ & 0 & 0 & & 22 & 1.9 & 100 \\
\hline Heavy Users & & 1182 & 100.0 & & 1182 & 100.0 & \\
\hline
\end{tabular}

APPENDIX 2.B

TENURE OF USING SOCIAL NETWORKING SITES (SNSS) AND INSTALLED MOBILE MESSAGING APPLICATIONS (MMAS)

\begin{tabular}{|l|c|c|c|c|c|c|c|}
\hline \multicolumn{3}{|l|}{ Use of Social Networking Sites (SNSs) } & \multicolumn{4}{|c|}{$\begin{array}{r}\text { Use of Mobile Messaging } \\
\text { Applications (MMAs) }\end{array}$} \\
\hline $\begin{array}{l}\text { Category of } \\
\text { Use }\end{array}$ & Frequency & Percent & $\begin{array}{c}\text { Cumulative } \\
\text { Percent }\end{array}$ & $\begin{array}{l}\text { Category of } \\
\text { Use }\end{array}$ & Frequency & Percent & $\begin{array}{c}\text { Cumulative } \\
\text { Percent }\end{array}$ \\
\hline $\begin{array}{l}\text { Don't/Can't } \\
\text { Use }\end{array}$ & 66 & 5.6 & 5.6 & Can't Use & 496 & 42.0 & 42.0 \\
\hline $\begin{array}{l}\text { Up to 2.5 } \\
\text { Hours }\end{array}$ & 990 & 83.8 & 89.3 & $\begin{array}{l}\text { Up to 04 } \\
\text { Hours }\end{array}$ & 680 & 57.5 & 99.5 \\
\hline $\begin{array}{l}\text { More than } \\
\text { 2.5 Hours }\end{array}$ & 126 & 10.7 & 100.0 & $\begin{array}{l}\text { More than } \\
\text { 04 Hours }\end{array}$ & 6 & .5 & 100.0 \\
\hline Total & 1182 & 100.0 & & Total & 1182 & 100.0 & \\
\hline
\end{tabular}


APPENDIX 3

FREQUENCY OF USING DIFFERENT SOCIAL NETWORKING SITES (SNSS) AND MOBILE MESSAGING APPLICATIONS (MMAS)

\begin{tabular}{|c|c|c|c|}
\hline & Frequency & Percent & Cumulative Percent \\
\hline \multicolumn{4}{|c|}{ Different Social networking sites and their frequency of use } \\
\hline Facebook & 1046 & 88.5 & 88.5 \\
\hline Twitter & 26 & 2.2 & 90.7 \\
\hline Linkedin & 4 & .3 & 91.0 \\
\hline Pinterest & 4 & .3 & 91.4 \\
\hline MySpace & 1 & .1 & 91.5 \\
\hline GooglePlus+ & 14 & 1.2 & 92.6 \\
\hline Tagged & 1 & .1 & 92.7 \\
\hline CafeMoM & 7 & .6 & 93.3 \\
\hline Ning & 3 & .3 & 93.6 \\
\hline Meetup & 1 & .1 & 93.7 \\
\hline myLife & 1 & .1 & 93.7 \\
\hline I don't have any such type of account & 74 & 6.3 & 100.0 \\
\hline Total & 1182 & 100.0 & \\
\hline \multicolumn{4}{|c|}{ Different mobile massaging applications and their frequency of use } \\
\hline Line & 58 & 4.91 & 4.9 \\
\hline whatsApp & 48 & 4.06 & 9.0 \\
\hline Viber & 60 & 5.0 & 14.0 \\
\hline MessageMe & 81 & 6.85 & 20.9 \\
\hline eBuddy & 162 & 13.71 & 34.6 \\
\hline HeyTell & 14 & 1.19 & 35.8 \\
\hline TextNow & 53 & 4.48 & 40.3 \\
\hline NimBuzz & 130 & 11.0 & 51.3 \\
\hline WeChat & 60 & 5.0 & 56.3 \\
\hline SNSpchat & 2 & .2 & 56.5 \\
\hline Others & 18 & 1.52 & 58.0 \\
\hline $\begin{array}{l}\text { My cell phone doesn't support such } \\
\text { type of applications }\end{array}$ & 496 & 42 & 100.0 \\
\hline Total & 1182 & 100.0 & \\
\hline
\end{tabular}




\section{REFERENCES}

Ahmed, I. and Qazi, F. T. (June) 'A look out for academic impacts of social networking sites (SNSs): A student based perspective', African Journal of Business Management, 5(12), 5022-5031.

Akhter, M. M. Siddique, M. N. and Masum, A. A (2011) 'Analysis of Social Network and its Effect on Job Satisfaction and Employee Performance'. ASA University Review, 5(1), 195-207

Alam, M.J.B., Kabir, S.M.L and Elizabeth, H. (2006) 'E-Learning in Bangladesh: Implementation and Evaluation of a Pilot Project', Retrieved from http://www.codewitz.net/papers/MMT_77-82_e-Learning_in_Bangladesh.pdf,

Alam, M. S. (2013) 'Future Prospect of $3 G$ Network in Bangladesh', National Conference on Need Assessment of B.Sc. Engineering in CSE Program, February 20, 2013.

Anderson, J. Q. and Rainie, L. (2012) 'Millennials will benefit and suffer due to their hyperconnected lives', Washington DC: Pew Research Center.

Anderson, K. (1999) 'Internet use among college students: Should we be concerned?', Paper presented at the American Psychological Association, Boston, MA.

Asad, S., Mamun, M.A. and Clement, C.K. (2012) 'The Effect of Social Networking Sites to the Lifestyles of Teachers and Students in Higher Educational Institutions', International Journal of Basic and Applied Sciences, Vol. 1 Iss. 4, PP. 498-510.

Azam, M. S. (2007) 'Internet Adoption and Usage in Bangladesh. Japanese Journal of Administrative Science' Volume20, No.1, 2007, pp. 43-54.

Barratt, W., Hendrickson, M., Stephens, A. and Torres, J. (2005) 'Thefacebook.com: Computer mediated social networking', Student Affairs Online, 6(1), 1-5.

Boyd, D., \& Ellison, N. (2007) 'Social Network Sites: Definition, History and Scholarship', Journal of Computer-Mediated Communication, 13(1).

Brenner, V. (1997) 'Psychology of computer use: XLVII. Parameters of Internet use, abuse and addiction: The first 90 days of the Internet usage survey', Psychological Reports, 80, pp. 879-882.

Briggs, S.R. and Cheek, J.M. (1986) 'The role of factor analysis in the development and evaluation of personality scales', Journal of Personality, 54, 106-48.

Bryer, T. and Zavattaro, S. (2011) 'Social media and public administration: Theoretical dimensions and introduction to symposium', Administrative Theory \& Praxis, 33(3), 327.

Canales, C., Wilbanks, B. and Yeoman, A. (2009) 'Facebook Usage in Relation to Personality and Academic Performance', Modern Psychological Studies, Spring.

Chen, B. and Bryer, T. (2012)'Investigating Instructional Strategies for Using Social Media in Formal and Informal Learning', The International Review of Research in Open and Distance Learning,13(1), 87-104.

Connolly, M. (2011, October) 'Benefits and Drawbacks of Social Media in Education', Retrieved from Wisconsin Center for Education Research: http://www.wcer.wisc.edu/news/coverstories/2011/benefits_and_drawbacks.php

DeVellis, R.F. (2003) 'Scale development: Theory and applications (2nd edn)' Thousand Oaks, California: Sage 
Debnath, N. C. and Mahmud, A. A. (2007) 'The Environment of E-Commerce in Bangladesh', Daffodil International University Journal of Business and Economics, 2(2).

Down, B. (2009) 'Schooling, Productivity and the Enterprising Self: Beyond Market Values', Critical Studies in Education, 50(1).

EU. (2009) 'Safer Social Networking Principles for the EU', European Commission.

Gonzalez, N. 'CheckFacebook.com: Facebook marketing statistics, demographics, reports, and news', Retrieved from: http://www.checkfacebook.com, Accessed December 8, 2013.

Hampton, K. N., Sessions-Goulet, L., Rainie, L., \& Purcell, K. (2011) 'Social networking sites and our lives', Washington, DC: Pew Research Center.

Hargittai, E., \& Hsieh, Y. P. (2010, June) 'Predictors and Consequences of Differentiated Practices on Social Network Sites', Information, Communication \& Society, 13(4), pp. 515-536.

Horn, S. (1998) 'Cyberville: Clicks, culture, and the creation of an online town', New York: Warner Books.

Internet World Stats: Usage and Population Statistics' (2004), at http://www.internetworldstats.com/, accessed 02 January 2014.

Junco, R., Heibergert, G. and Loken, E. (2011) 'The effect of Twitter on college student engagement and grades', Journal of Computer Assisted Learning, 27, 119-132.

Karpinski, A. C., \& Duberstein, A. (2009, April) 'A Description of Facebook Use and Academic Performance among Undergraduate and Graduate Students', San Diego, California: American Educational Research Association.

Katz, J., \& Aspden, P. (1997) 'A nation of strangers? Friendship patterns and community involvement of Internet users', Communications of The ACM, 40, pp. 81-86.

Kolek, E. A. and Saunders, D. (2008) 'Online disclosure: An empirical examination of undergraduate Facebook profiles',NASPA Journal, 45(1), 1-25.

Kraut, R., Lundmark, V., Patterson, M., Kiesler, S. and Mukapadhyay, T. (1998) 'Internet Paradox: A Social Technology that Reduces Social Involvement and Psychological Well-being?', American Psychologist, 53: 1017-1031.

Kraut, R., Patterson, M., Lundmark, V., Kiesler, S., Mukophadhyay,T., \& Scherlis, W. (1998) 'Internet paradox: A social technology that reduces social involvement and psychological well-being?', American Psychologist, 53(9), pp. 1017-1031.

Kubey, R. W., Lavin, M. J. and Barrows, J. R. (2001)'Internet use and collegiate academic performance decrements: Early findings', Journal of Communication, 51, 366-382.

Lane, Barney (2006), 'The Economic and Social Benefits of Mobile Services in Bangladesh: A case study for the GSM Association'. Retrieved from: http://www.dirsi.net/english/files/Ovum\%20Bangladesh\%20Main\%20report1f.pdf

Lenhart, A. (2009) 'Teens and Social Media: An Overview', New York: Pew Internet \& American Life Project.

Madge, C., Meek, J., Wellens, J. and Hooley, T. (2009) 'Facebook, social integration and informal learning at university: It is more for socializing and talking to 
friends about work than for actually doing work', Learning, Media, and Technology, 34 (2), 141-155.

Mafiz, A. I., Ismail, I. and Bhuyan, M. A. H. (2011) 'Effects of Socio-economic, Demographic and Internet Exposure Factors on School Performance among Selected Students of Nilkhet High School', Bangladesh Journal of Nutrition, Vol. 24-25, PP. 107-120.

Mahmud, M. A. A. (2011) 'Student's Attitudes towards Internet: A study on Private University of Bangladesh', European Journal of Business and Management, Vol. 3 Issn. 2222-1905(paper), Issn 2222-2839 (online)

Mohseni, M., Dowra, B. and Haghighat, M.H.S. (2008), 'Does the Internet Make People Socially Isolated?', A Social Network Approach, Bangladesh e-Journal of Sociology, Volume 5 Number 1. January 2008.

McQuail, D. (2005) 'McQuail's Mass Communication Theory', 5th edition, London: Sage Publications.

Mostofa, Sk. M. (2011) 'Internet Access and Use among Business Students of a Private University of Bangladesh: A Survey', Annals of Library and Information Studies, 58, 78-85.

On Line (1996), 'Chronicle of Higher Education', 42(33), A21.

Pallant, J. (2010), 'SPSS Survival Manual: A step by step guide to data analysis using SPSS (4th ed.)', New York, NY: Open University Press.

Pasek, J., More, E. and Hargittai, E. (2009) 'Facebook and academic performance: Reconciling a media sensation with data',First Monday, 14(5).

Pew. (2009) 'Infographics. Retrieved 2012, from Pew Internet', http://pewinternet.org/Infographics/Generational-Differences-in-SNS.aspx.

Phusavat, K., Ketsarpong, S., Ooi, K.-B., \& Shyu, S. (2012) ' Sustaining higer educatino reforms: Knowledge and policy implications learned from Thailand', International Journal of Educational Management, 26(3), 284-301.

Rahaman, Arafatur, Ullah, G. M. Shafayet(2013), 'Exploration Of Influencing Factors That Effecting Facebook Privacy Awareness On Bangladeshi Undergraduate University Student's', International Journal Of Scientific \& Technology Research Volume 2, Issue 6, June 2013.

Rahman, Sayeedur (2002) 'Internet in Bangladesh', at http://www.eela.com/computer/InternetBD_122202.html, accessed 21 November 2013.

Rainie, L. (2011, November) 'The new education ecology', Powerpoint presentation, Orlando, Florida.

Rizzuto, T. E., LeDoux, J., and Hatala, J. P. (2009) 'It's not just what you know, it's who you know: Testing a model of the relative importance of social networks to academic performance', Social Psychology Education, 12, 175-189.

Roknuzzaman, M.(2006) 'A survey of Internet access in a large public university in Bangladesh', International Journal of Education and Development using Information and Communication Technology(IJEDICT), 2006, Vol. 2, Issue 3, pp. 86-105.

Rosen, L. (2011, August) 'Poke Me: How Social Networks Can Both Help and Harm Our Kids', Washington, DC: American Psychological Association. 
Rouis, S., Limayem, M. and Salehi-Sangari, E. (2011) 'Impact of Facebook Usage on Students' Academic Achievement: Role of Self-Regulation and Trust,' Journal of Research in Educational Psychology, 9(3), 961-994.

Scherer, K. (1997) 'College life online: Healthy and unhealthy Internet use', Journal of College Student Development, 38(6), 655-665.

Stollak, M. J., Vandenberg, A., Burklund, A. and Weiss, S. (2011) 'Getting Social: The Impact of Social Networking Usage on grades Among College Students', American Society of Business and Behavioral Sciences, 18(1), 859-865.

Tabachnick, R.G. and Fidell, L.S. (1996), 'Using multivariate statistics (3rd edition)', New York: HarperCollins, Chapter 13.

Tofazzal, I. M., Abu S. M. S. (2006), 'Current Status and Prospects for E-learning in the Promotion of Distance Education in Bangladesh', Turkish Online Journal of Distance Education, 7(1). ISSN 1302-6488

Wang, Q., Chen, W. and Liang, Y. (2011) 'The Effects of Social Media on College Students. The Alan Shawn Feinstein Graduate School', Providence: Johnson \& Wales University.

Yazedjian, A., Toews, M. and Sevin, T. (2008) 'It's a whole new world: a qualitative exploration of college students' definitions of and strategies for college students', Journal of College Student Development, 49 (2), 141-154.

Young, K. (1996) 'Internet addiction: The emergence of a new clinical disorder,' [Online], Available: http://www.pitt.edu/ ksy/apa.html.

Zaman, Farhana.Chowdhury, Priyabrata (2012), 'Technology Driven Banking in Bangladesh: Present Status, Future Prospects and Challenges', BUP JOURNAL, Volume 1, Issue 1. ISSN: 2219-4851.

Zwart, M. d., Lindsay, D., Henderson, M., \& Phillips, M. (2011) 'Teenagers, Legal Risks and Social Networking Sites', Victoria, Australia: Victoria Law Foundation.

i According to Pallant $\left(2010^{\mathrm{i}}\right)$, “...Cronbach alpha values are, however, quite sensitive to the number of items in the scale. With short scales (e.g. scales with fewer than ten items) it is common to find quite low Cronbach values (e.g. .5). In this case, it may be more appropriate to report the mean inter-item correlation for the items. Briggs and Cheek (1986 ${ }^{\mathrm{i}}$ ) recommend an optimal range for the inter-item correlation of .2 to .4. (Pallant, 2010)".

ii According to Tabachnick and Fidell (2007, P. 75) maximum value above 01 refers to a potential problem. 